-Full Paper-

\title{
Consequences for the Bovine Embryo of Being Derived from a Spermatozoon Subjected to Post-Ejaculatory Aging and Heat Shock: Development to the Blastocyst Stage and Sex Ratio
}

\author{
Katherine Elizabeth May HENDRICKS ${ }^{1}$, Leydson MARTINS ${ }^{1,2)}$ and Peter James HANSEN ${ }^{1)}$ \\ ${ }^{1)}$ Department of Animal Sciences, University of Florida, Gainesville, FL 32611, USA and ${ }^{2)}$ Universidade de São Paulo, \\ Faculdade de Medicina Veterinária e Zootecnia, São Paulo, Brazil
}

\begin{abstract}
The objective was to determine whether aging of sperm caused by incubation at normothermic (38.5 C) or heat shock $(40 \mathrm{C})$ temperatures for $4 \mathrm{~h}$ prior to oocyte insemination affects sperm motility, fertilizing ability, competence of the resultant embryo to develop to the blastocyst stage and blastocyst sex ratio. In the first experiment, the percent of sperm that were motile was reduced by aging $(\mathrm{P}<0.001)$ and the reduction in motility was greater for sperm at $40 \mathrm{C}$ compared to sperm at $38.5 \mathrm{C}(\mathrm{P}<0.01)$. In the second experiment, oocytes were inseminated with aged sperm. A smaller percent of oocytes fertilized with sperm aged at either temperature cleaved by Day 3 after insemination than oocytes fertilized with fresh sperm $(\mathrm{P}<0.05)$. There was no effect of sperm aging on the percent of oocytes or cleaved embryos that developed to the blastocyst stage. Aging of sperm before fertilization at $38.5 \mathrm{C}$ reduced the percent of blastocysts that were male $(\mathrm{P}=0.08)$. In the third experiment, incubation of sperm at $38.5 \mathrm{C}$ or $40 \mathrm{C}$ for $4 \mathrm{~h}$ did not reduce fertilizing ability of sperm as determined by pronuclear formation at $18 \mathrm{~h}$ post insemination. In conclusion, aging of sperm reduced cleavage rate and the percent of blastocysts that were males but had no effect on the developmental capacity of the embryo. The effect of aging on cleavage rate may represent reduced motility and errors occurring after fertilization and pronuclear formation. Aging at a temperature characteristic of maternal hyperthermia had little additional effect except that polyspermy was reduced. Results indicate that embryo competence for development to the blastocyst stage is independent of sperm damage as a result of aging for $4 \mathrm{~h}$ at normothermic or hyperthermic temperatures.
\end{abstract}

Key words: Aging, Bovine, Fertilization, Heat shock, Spermatozoa

(J. Reprod. Dev. 55: 69-74, 2009)

D evelopmental competence of the mammalian embryo is dependent on genetic and non-genetic contributions from its parents [1-6]. Sperm could affect an embryo's competence for development if the timing of fertilization or early cleavage is delayed. For example, embryos produced by high-fertility bulls entered S-phase of the first cell cycle earlier and had a longer S-phase than those produced by low-fertility bulls [7]. In another study, spermatozoa from $50 \%$ of bulls identified as being of low fertility in artificial insemination studs experienced premature capacitation [8]. Damage to the macromolecular portions of the sperm that are incorporated by the embryo could also result in formation of embryos with reduced developmental competence. Among these sperm contributions are DNA, the centriole [9], and RNA [10]. Embryos fertilized with semen containing a high proportion of sperm with extensive DNA damage have reduced competence for development [11-13] but the importance of damage to the centriole or sperm RNA is not known.

Damage to sperm can occur in the male reproductive tract or after deposition of sperm in the female. In bulls, for example, thermal stress of the scrotum leads to production of sperm that produce embryos with delayed or reduced pronuclear formation [14], a reduced ability of cleaved embryos to become blastocysts for some bulls [15, 16], and increased embryo apoptosis [17]. Sperm from

Accepted for publication: October 6, 2008

Published online in J-STAGE: October 28, 2008

Correspondence: PJ Hansen (e-mail: hansen@animal.ufl.edu) diabetic mice have reduced capacity to fertilize oocytes and for the resultant embryos to give rise to blastocysts [18]. There is also evidence that sperm can be damaged after ejaculation by stresses that lead to reduced embryo competence after fertilization. X-irradiation of mouse sperm did not affect fertilizing ability but did reduce rates of blastocyst development and implantation [19]. Exposure of ejaculated frozen-thawed bull spermatozoa to gossypol [20] or reactive oxygen species reduced the percent of cleaved embryos that developed to the blastocyst stage [21].

For the current study, we used bull spermatozoa to test the hypothesis that aging of ejaculated sperm for $4 \mathrm{~h}$ after freeze-thawing would damage sperm and lead to embryos with reduced developmental competence after fertilization. The term 'aging' was used to represent incubation in vitro since this treatment can cause a reduction in sperm motility after $3 \mathrm{~h}$ [22]. A second hypothesis was that sperm damage would be enhanced if aging occurred at elevated temperatures. The heat-stress temperature used, $40 \mathrm{C}$, is characteristic of rectal temperatures of lactating cows exposed to heat stress $[23,24]$ and effects of aging sperm at this temperature could be relevant to understanding causes of reduced fertility of dairy cows during heat stress [25]. Exposure of human ejaculated sperm to mild heat shock caused DNA damage [26] and studies in the rabbit indicate that fertilization with sperm incubated at elevated temperature in vitro or in the female rabbit results in embryos with reduced implantation rates [27, 28]. 


\section{Materials and Methods}

\section{Materials}

The media HEPES-Tyrodes Lactate (HEPES-TL), IVF-TL, and Sperm-TL were purchased from Caisson (Sugar City, ID, USA) and used to prepare HEPES-Tyrodes albumin lactate pyruvate (TALP), IVF-TALP, and Sperm-TALP as previously described [29]. Oocyte collection medium (OCM) was Tissue Culture Medium-199 (TCM-199) with Hank's salts without phenol red (Atlanta Biologicals, Norcross, GA, USA) supplemented with 2\% $(\mathrm{v} / \mathrm{v})$ bovine steer serum (Pel-Freez, Rogers, AR) containing $2 \mathrm{U} /$ $\mathrm{ml}$ heparin, $100 \mathrm{U} / \mathrm{ml}$ penicillin-G, $0.1 \mathrm{mg} / \mathrm{ml}$ streptomycin, and 1 $\mathrm{mM}$ glutamine. Oocyte maturation medium (OMM) was Tissue Culture Medium 199 (Gibco $^{\circledR}$, Invitrogen, Carlsbad, CA, USA) with Earle's salts supplemented with $10 \%(\mathrm{v} / \mathrm{v})$ bovine steer serum, $2 \mu \mathrm{g} / \mathrm{ml}$ estradiol 17- $\beta, 20 \mu \mathrm{g} / \mathrm{ml}$ bovine FSH (Folltropin-V; Bioniche Animal Health, London, ON, Canada), $22 \mu \mathrm{g} / \mathrm{ml}$ sodium pyruvate, $50 \mu \mathrm{g} / \mathrm{ml}$ gentamicin sulfate, and $1 \mathrm{mM}$ glutamine. Percoll was from GE Healthcare (Uppsala, Sweden). Potassium simplex optimized medium (KSOM) containing $1 \mathrm{mg} / \mathrm{ml}$ BSA was obtained from Caisson. Essentially fatty-acid free (EFAF) BSA was from Sigma-Aldrich (St. Louis, MO, USA). On the day of use, KSOM was modified for bovine embryos to produce KSOM-BE2 as described elsewhere [30]. Hoechst 33342 was from Calbiochem (San Diego, CA, USA). PCR oligonucleotide primers were obtained from Integrated DNA Technology (Coralville, IA, USA). Taq DNA polymerase and $100 \mathrm{mM}$ dNTPs were from Invitrogen. All other reagents were purchased from Sigma-Aldrich or Fisher Scientific (Pittsburgh, PA, USA) unless otherwise stated.

\section{Sperm preparation}

Extended and frozen semen from Holstein bulls was obtained from Select Sires (Plain City, OH, USA) and ABS Global (Deforest, WI, USA). Semen was thawed, subjected to Percoll gradient purification to obtain motile spermatozoa [29], diluted in SpermTALP medium to $20 \times 10^{6} \mathrm{spermatozoa} / \mathrm{ml}$, and aged by incubation at 38.5 or $40 \mathrm{C}$ in air for $4 \mathrm{~h}$ using a water bath. Additional semen was thawed to prepare a non-incubated spermatozoa control. In this case, semen was thawed, subjected to Percoll purification, and diluted to $20 \times 10^{6}$ spermatozoa/ml at a time to coincide with the end of the incubation period for aged sperm.

\section{Sperm motility}

The percent of sperm exhibiting motility was assessed by visual examination. Briefly, $20 \mu \mathrm{l}$ of sperm suspension were placed on a glass slide pre-warmed at $37 \mathrm{C}$ and examined under 200× magnification. Motility was estimated for 100 spermatozoa located in 10 different fields.

\section{In vitro production of embryos}

Embryo production was performed as previously described [30] except that sperm were subjected to incubation prior to fertilization as described above and oocytes in a single replicate were inseminated with semen from a single bull. Briefly, cumulus-oocyte complexes (COCs) were obtained by slicing 2 to $10 \mathrm{~mm}$ follicles on the surface of ovaries (a mixture of beef and dairy cattle) obtained from a local abattoir. COCs containing at least one layer of compact cumulus cells were selected for maturation and fertilization. They were washed twice in OCM and placed in groups of 10 in $50 \mu$ drops of OMM overlaid with mineral oil and matured for $22 \mathrm{~h}$ at $38.5 \mathrm{C}, 5 \% \mathrm{CO}_{2}$ in humidified air. Matured oocytes where then washed once in HEPES-TALP and transferred in groups of 30 to 4 -well-plates containing $600 \mu$ IVF-TALP per well and $25 \mu \mathrm{l}$ PHE [(0.5 mM penicillamine, $0.25 \mathrm{mM}$ hypotaurine, and $25 \mu \mathrm{M}$ epinephrine in $0.9 \%(\mathrm{w} / \mathrm{v}) \mathrm{NaCl})]$ per well and fertilized with $25 \mu \mathrm{l}\left(5 \times 10^{5}\right)$ Percoll-purified spermatozoa from a single Holstein bull. After $8 \mathrm{~h}$ of co-incubation at $38.5 \mathrm{C}, 5 \% \mathrm{CO}_{2}$ in humidified air, putative zygotes were removed from fertilization wells and denuded of cumulus cells by vortexing in $100 \mu$ l hyaluronidase $(1,000 \mathrm{U} / \mathrm{ml}$ in approximately $0.5 \mathrm{ml}$ HEPES-TALP). Denuded putative zygotes were cultured in groups of 25-30 in 50$\mu \mathrm{l}$ drops of KSOM-BE2 overlaid with mineral oil at 38.5 $\mathrm{C}$ in a humidified atmosphere of $5 \% \mathrm{CO}_{2}, 5 \% \mathrm{O}_{2}$ and the balance nitrogen. Fertilization was assessed at $18 \mathrm{~h}$ post-insemination (hpi), cleavage was assessed on Day 3 after insemination and presence of blastocysts was determined on Day 7 and/or Day 8 after insemination.

\section{Determination of fertilization}

Inseminated oocytes were transferred at $18 \mathrm{hpi}$ from KSOMBE2, washed in $10 \mathrm{mM} \mathrm{KPO}_{4}(\mathrm{pH} \mathrm{7.4)}$ containing $0.9 \%(\mathrm{w} / \mathrm{v})$ $\mathrm{NaCl}$ (PBS) and $1 \mathrm{mg} / \mathrm{ml}$ polyvinylpyrollidone (PVP) (PBS-PVP) and transferred onto poly-L-lysine coated slides. Slides were allowed to air dry and fixed overnight in $100 \%$ ethanol and then stained with Hoechst 33342 ( $1 \mu \mathrm{g} / \mathrm{mL}$ in PBS-PVP) for $10 \mathrm{~min}$ in the dark at room temperature. Slides were washed three to four times with PBS-PVP, and cover slips mounted using $5 \mu \mathrm{l}$ mounting medium containing ProLong ${ }^{\circledR}$ Gold antifade reagent (Invitrogen). Pronuclei of inseminated oocytes were identified by fluorescence using a Zeiss Axioplan 2 fluorescence microscope (Carl Zeiss, Göttingen, Germany) with an ultraviolet excitation filter. Oocytes were classified in four groups: $\mathrm{X}$, unknown, unable to assess presence of pronuclei; $\mathrm{M}$, unfertilized oocyte in Metaphase II with one polar body visible; $1 \mathrm{PN}$, presence of a single decondensed pronucleus; $2 \mathrm{PN}$, presence of two pronuclei, indicative of fertilization; and PPN; presence of 3 or more pronuclei. Oocytes with two pronuclei (2PN) were considered as fertilized and those with more than 2PN were considered as fertilized but polyspermic.

\section{Embryo sex determination}

Blastocysts were removed from culture drops, washed in PBSPVP and transferred into a solution of $0.1 \%(\mathrm{w} / \mathrm{v})$ protease from Streptomyces griseus (Sigma) in PBS for 1.5 min. Embryos were then washed 3 times in $150 \mu$ PBS-PVP, collected individually in $10 \mu \mathrm{l}$ drops of $0.1 \%(\mathrm{w} / \mathrm{v})$ diethylpyrocarbonate in water, transferred into $0.2 \mathrm{ml}$ PCR tubes and stored at $-20 \mathrm{C}$ until analysis. To prepare samples for PCR, tubes were thawed at room temperature and centrifuged at $2,000 \times \mathrm{g}$ for $5 \mathrm{sec}$, heated to $98 \mathrm{C}$ for $10 \mathrm{~min}$ and centrifuged at 2,000 $\times$ g for $5 \mathrm{sec}$ prior to addition of PCR reagents.

Two sets of PCR primers were used to determine embryo sex: Y-chromosome specific primers that amplify a 141 bp product and 
auotosomal bovine-specific satellite sequence primers that amplify a 216 bp product [31]. The amplification reactions were conducted in a total volume of $20 \mu \mathrm{l}$. The first amplification consisted of $10 \times$ PCR buffer, $2.5 \mathrm{mM}$ dNTPs, $50 \mathrm{mM} \mathrm{MgCl}_{2}, 1$ unit of Taq DNA polymerase and $10 \mu \mathrm{M} Y$-specific forward primer (5'-GATCACTATACATACACCACT-3') and $10 \mu \mathrm{M}$ Y-specific reverse primer (5'-GCTATGCTAACACAAATTCTG-3'). The first PCR was programmed for an initial denaturation at $95 \mathrm{C}$ for $7 \mathrm{~min}$ followed by 10 cycles of $95 \mathrm{C}$ for $30 \mathrm{sec}, 55 \mathrm{C}$ for $30 \mathrm{sec}$ and $72 \mathrm{C}$ for $30 \mathrm{sec}$; after the 10 cycles the reaction mixtures were kept at $72 \mathrm{C}$ for 7 min. Tubes were centrifuged at $2000 \times \mathrm{g}$ for $5 \mathrm{sec}$ prior to addition of the second PCR mix for autosomal primers containing $10 \mu \mathrm{M}$ forward (5'-TGGAAGCAAAGAACCCCGCT-3') and $10 \mu \mathrm{M}$ reverse primers (5'-TCGTCAGAAACCGCACACTG-3'). The second PCR was programmed for initial denaturation at $95 \mathrm{C}$ for 7 min, 30 cycles of $95 \mathrm{C}$ for $30 \mathrm{~s}, 55 \mathrm{C}$ for $30 \mathrm{sec}$ and $72 \mathrm{C}$ for $30 \mathrm{sec}$, and a final step at $72 \mathrm{C}$ for $7 \mathrm{~min}$. PCR amplification products were separated by electrophoresis on $3 \%(\mathrm{w} / \mathrm{v})$ agarose gels in a $1 \times \mathrm{TBE}$ buffer (89 mM Tris, $88.9 \mathrm{mM}$ boric acid, $2.2 \mathrm{mM}$ EDTA, pH 8.3) containing $10 \mu \mathrm{g} / \mathrm{ml}$ ethidium bromide.

\section{Experiments}

The first experiment tested the effects of aging on sperm motility. Sperm motility was assessed for non-incubated sperm immediately following Percoll purification and for sperm at the end of the incubation period at 38.5 or $40 \mathrm{C}$ in air for $4 \mathrm{~h}$ using a water bath. The experiment was replicated a total of 21 times with sperm from 17 bulls.

The second experiment tested effects of aging on cleavage rate and development to the blastocyst stage when oocytes were fertilized for $8 \mathrm{~h}$. Oocytes were fertilized with unincubated control sperm, sperm aged at $38.5 \mathrm{C}$ or sperm aged at $40 \mathrm{C}$. Another group of oocytes remained unfertilized (i.e., incubation of oocytes in fertilization medium without sperm) to determine parthenogenesis. After fertilization for $8 \mathrm{~h}$, oocytes (fertilized, i.e., putative zygotes, and unfertilized, possible parthenotes) were placed in groups of 25-30 in $50 \mu \mathrm{l}$ microdrops of KSOM-BE2 at $38.5 \mathrm{C}$ in a humidified atmosphere of $5 \% \mathrm{CO}_{2}, 5 \% \mathrm{O}_{2}$ and the balance nitrogen. Cleavage was accessed on Day 3 after insemination and blastocyst development on Day 8 after insemination. The experiment was replicated a total of 11 times with a different bull for each replicate and with a total of 226-853 oocytes/group. For 10 of these replicates, blastocysts were harvested at Day 7 and again at Day 8 for determination of embryo sex.

A third experiment was designed to determine the effect of aging on fertilization. Oocytes were fertilized with unincubated control sperm, sperm aged at $38.5 \mathrm{C}$ or sperm aged at $40 \mathrm{C}$. After fertilization for $8 \mathrm{~h}$, oocytes (i.e., putative zygotes) were placed in groups of 25-30 in drops of KSOM-BE2 medium until processing for fertilization determination at $18 \mathrm{hpi}$ at $38.5 \mathrm{C}$ in an humidified atmosphere of $5 \% \mathrm{CO}_{2}, 5 \% \mathrm{O}_{2}$ and the balance nitrogen (v/v). The experiment was replicated three times using a different bull for each replicate and with a total of 59-72 inseminated oocytes/group COCs.

\section{Statistical analyses}

For each replicate, percent sperm that were motile, percent of oocytes that were fertilized, cleaved or developed to the blastocyst stage, percent of cleaved embryos that became blastocysts, and percent of blastocysts that were male were calculated for all oocytes or embryos within the same treatment. Thus, the group of embryos treated alike within each replicate was the experimental unit. Data were subjected to least squares analysis of variance using the GLM procedure of the Statistical Analysis System (SAS for Windows, Release 9.0, SAS Institute, Cary, NC, USA). Data were analyzed without transformation and again after arcsin transformation to correct for any non-normality associated with percentage data. The mathematical model included effects of bull, sperm treatment and treatment $\times$ bull (i.e., error). Data are reported as least-squares means \pm SEM from the analysis of the untransformed data while probability values are derived from analyses of transformed data. The CONTRAST statement of SAS was utilized to compare individual treatments.

Treatment effects on sex ratio were determined by logistic regression using the logistic procedure of SAS. Two comparisons were made: between control sperm and sperm aged at $38.5 \mathrm{C}$ and between control sperm and sperm aged at $40 \mathrm{C}$.

\section{Results}

\section{Sperm motility}

As compared to nonincubated control sperm (79.3 $\pm 1.8 \%)$, a fewer percentage of sperm exhibited motility after aging for $4 \mathrm{~h}$ at either 38.5 C or $40 \mathrm{C}(\mathrm{P}<0.001)$. Moreover, motility was lower $(\mathrm{P}<0.01)$ for sperm aged at $40 \mathrm{C}$ than for sperm aged at $38.5 \mathrm{C}$ (38.3 \pm 1.8 vs. $46.6 \pm 1.8 \%)$.

\section{Cleavage and development to the blastocyst stage}

As compared to oocytes inseminated with control sperm, cleavage rate was lower for oocytes inseminated with sperm aged at 40 $\mathrm{C}(\mathrm{P}<0.05)$ and tended to be lower $(\mathrm{P}=0.08)$ for oocytes inseminated with sperm aged at $38.5 \mathrm{C}$ (Table 1 ). However, there was no significant difference in cleavage rates between oocytes produced from sperm pre-incubated at $38.5 \mathrm{C}$ vs. $40 \mathrm{C}$. There was no effect of aging at either temperature on the percent of oocytes that became blastocysts or on the percent of cleaved embryos that became blastocysts (Table 1 ).

\section{Fertilization}

The effects of aging on the proportion of oocytes fertilized after $8 \mathrm{~h}$ was evaluated by counting the number of pronuclei at $18 \mathrm{hpi}$ (Table 2). Overall fertilization rate, as determined by the proportion of embryos with at least two pronuclei, was not affected by aging of sperm at $38.5 \mathrm{C}$ or at $40 \mathrm{C}$. Similarly, the percent of oocytes that were fertilized with a single spermatozoon (i.e., those with two pronuclei) was similar for all three groups and not affected by treatment. The percent of oocytes undergoing polyspermy (i.e., those with more than two pronuclei) tended $(\mathrm{P}=$ 0.08 ) to be lower for oocytes fertilized with sperm aged at $40 \mathrm{C}$ as compared to the controls. Aging at $38.5 \mathrm{C}$ did not affect rate of polyspermy. 
Table 1. Effect of sperm aging on cleavage rate and blastocyst development following insemination of matured oocytes with sperm for $8 h^{\mathrm{ab}}$

\begin{tabular}{lcccc}
\hline Treatment & $\mathrm{n}^{\mathrm{c}}$ & Cleavage (\%) & Blastocysts/oocyte (\%) & Blastocyst/cleaved embryo (\%) \\
\hline Control & 367 & $65.7 \pm 4.7$ & $30.4 \pm 3.0$ & $46.6 \pm 3.6$ \\
38.5 C & 845 & $56.6 \pm 2.7^{\dagger}$ & $28.9 \pm 1.7$ & $50.9 \pm 2.1$ \\
40 C & 853 & $52.2 \pm 2.7^{*}$ & $25.1 \pm 1.7$ & $46.9 \pm 2.1$ \\
Parthenogenesis & 226 & $3.5 \pm 2.7^{* * *}$ & $-0.3 \pm 1.7^{* * *}$ & $-0.3 \pm 2.1^{* * *}$ \\
\hline
\end{tabular}

${ }^{a}$ Data are least-squares means \pm SEM of the percent cleaved or percent blastocysts at Day 8 after insemination for each of 11 replicates; a separate bull was used for each replicate. ${ }^{\mathrm{b}}$ Means that differ from controls are indicated by superscripts: ${ }^{\dagger} \mathrm{P}=0.08$; ${ }^{*} \mathrm{P}<0.05$; ${ }^{* * *} \mathrm{P}<0.001$. There were no differences between 38.5 and $40 \mathrm{C}$. ${ }^{\mathrm{c}} \mathrm{n}$ : total number of embryos evaluated per treatment.

Table 2. Fertilization rate at $18 \mathrm{~h}$ post-insemination as affected by aging of sperm at 38.5 or $40 \mathrm{C}$ for $4 \mathrm{~h}^{\text {a }}$

\begin{tabular}{lcccc}
\hline \multirow{2}{*}{ Treatment } & & \multicolumn{2}{c}{ Percent fertilized } & Percent polyspermy \\
\cline { 2 - 5 } & $\mathrm{n}^{\mathrm{b}}$ & $\geq 2 \mathrm{PN}$ & $2 \mathrm{PN}$ & $>2 \mathrm{PN}$ \\
\hline Control & 64 & $79.8 \pm 8.8$ & $63.0 \pm 8.6$ & $16.8 \pm 3.5$ \\
$38.5 \mathrm{C}$ & 72 & $74.0 \pm 8.8$ & $60.1 \pm 8.6$ & $13.9 \pm 3.5$ \\
$40 \mathrm{C}$ & 59 & $66.3 \pm 8.8$ & $61.3 \pm 8.6$ & $5.0 \pm 3.5^{\dagger}$ \\
\hline
\end{tabular}

${ }^{a}$ Data are least-squares means \pm SEM of the percent fertilized or percent polyspermy for each of three replicates using a separate bull for each replicate. There were no differences between 38.5 and $40 \mathrm{C} .{ }^{\mathrm{b}} \mathrm{n}$ : total number of oocytes evaluated per treatment; $\geq 2 \mathrm{PN}$ : embryos having 2 or more pronuclei; 2PN: embryos having 2 pronuclei. ${ }^{\dagger}$ Differs from control $(\mathrm{P}=0.08)$.

Table 3. Sex of blastocysts at Day 7 and Day 8 after insemination as affected by sperm aging at 38.5 or $40 \mathrm{C}$ for $4 \mathrm{~h}^{\mathrm{a}}$

\begin{tabular}{lccccccccc}
\hline \multirow{2}{*}{$\begin{array}{l}\text { Sperm } \\
\text { treatment }\end{array}$} & \multicolumn{3}{c}{ Blastocysts at Day 7 } & \multicolumn{3}{c}{ Blastocysts at Day 8 } & \multicolumn{3}{c}{ Day 7 and 8 combined } \\
\cline { 2 - 10 } & $\mathrm{n}$ & $\mathrm{M}$ & \% Male & $\mathrm{n}$ & $\mathrm{M}$ & \% Male & $\mathrm{n}$ & M & \% Male \\
\hline Control & 78 & 45 & 57.7 & 47 & 28 & 59.6 & 125 & 73 & 58.4 \\
38.5 C & 77 & 35 & 45.5 & 48 & 23 & 47.9 & 125 & 58 & $46.4^{\dagger}$ \\
40 C & 80 & 42 & 52.5 & 37 & 19 & 51.4 & 117 & 61 & 52.1 \\
\hline
\end{tabular}

${ }^{a} \mathrm{n}$ : total number of blastocysts evaluated per treatment; M: total number of embryos that were males. ${ }^{\mathrm{b}}$ Blastocysts at Day 8 represent embryos that were not blastocysts at Day 7 but which became blastocysts by Day 8. ${ }^{\dagger}$ Differs from control $(\mathrm{P}=0.08)$.

\section{Sex of blastocysts}

A total of 375 blastocysts were produced and 367 of these were successfully sexed. PCR reactions in which there were two amplicons (for Y-specific primers and for autosomal primers) were classified as males while those exhibiting an autosomal amplicon only were classified as female (Fig. 1). The effect of sperm treatment on the proportion of blastocysts at Day 7 and 8 that were male is presented in Table 3. For embryos produced from oocytes inseminated with non-incubated sperm, there was a preponderance of male blastocysts at both Day 7 (57.5\%) and Day 8 (59.6\%) after insemination. The percent of blastocysts that were male was reduced for embryos produced with sperm aged at $38.5 \mathrm{C}(\mathrm{P}=0.08)$ but not for embryos produced with sperm aged at $40 \mathrm{C}$.

\section{Discussion}

Aging of sperm after freeze-thawing reduced motility but had no effect on the fertilizing ability of bovine spermatozoa, a slight effect only on the proportion of oocytes cleaving after insemination, and no effect on the competence of the resultant embryo to

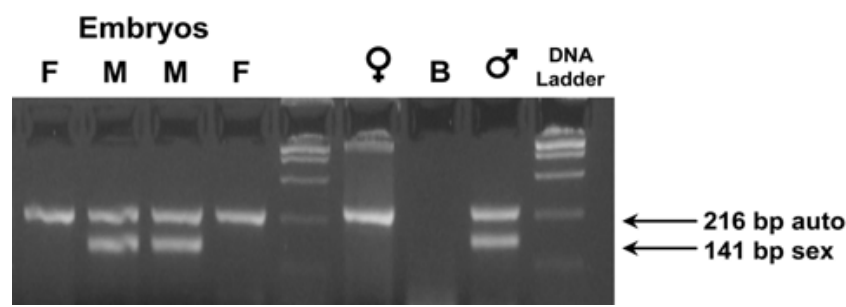

Fig. 1. Representative results for analysis of embryo sex by PCR. 우: Female bovine DNA isolated from whole blood; 3 : Male bovine DNA isolated from whole blood; B: blank - PCR reaction mixture without embryo. The amplicons for the Y-specific primer (141 bp) and autosomal primer (216 bp) are indicated by arrows. Note that embryos that produced both the 216 and 141 bp amplicons were classified as male (M), while those with only the 216 bp product were classified as female $(\mathrm{F})$.

develop to the blastocyst stage. Lack of effect of aging on embryo competence was true even when spermatozoa were incubated at a temperature of $40 \mathrm{C}$ that is characteristic of heat-stressed cows. 
Aging did affect sperm function, however, since sperm motility and cleavage rate was reduced and the blastocyst sex ratio tended to be altered by aging of sperm at 38.5 C.

Sperm survival after ejaculation is transient unless sperm are maintained with oviductal cells [32], cryopreserved or suspended in diluents designed to prolong viability while stored cold. Bull sperm incubated for $24 \mathrm{~h}$ at $39 \mathrm{C}$ had reduced competence for fertilizing oocytes as determined by subsequent cleavage [32, 33]. Even short-term aging can compromise sperm function. In this study, motility of bull sperm was decreased by $4 \mathrm{~h}$ incubation at $38.5 \mathrm{C}$ and slightly more so by incubation at $40 \mathrm{C}$. Previous work indicates bull sperm motility was decreased by as little as $3 \mathrm{~h}$ incubation at $39 \mathrm{C}$ [22]. The reduction in cleavage rate when oocytes were fertilized with sperm aged at $38.5 \mathrm{C}$ or $40 \mathrm{C}$ in the current study could reflect decreased sperm motility and fertilizing capacity. However, examination of pronuclear formation after fertilization failed to indicate a decline in fertilization rate in oocytes inseminated with aged sperm. It may be, therefore, that the reduction in cleavage rate in oocytes inseminated with aged sperm reflects a delay in fertilization and aging of the oocyte [34]. It is also possible that aging damaged the sperm centriole so that syngamy was compromised.

The lack of effects of aging on the proportion of inseminated oocytes or cleaved embryos that became blastocysts agrees with other studies finding no effect of aging sperm for 3-6 h at $39 \mathrm{C}$ on cleavage rate or on the proportion of oocytes becoming blastocysts [33, 35]. Embryos produced by sperm aged for $24 \mathrm{~h}$ did exhibit reduced competence for development however [33]. Aging in vivo is likely to result in less steep decline in sperm function than seen here because oviductal epithelial cells can maintain fertilizing capacity of bull spermatozoa for up to $30 \mathrm{~h}$ [32].

Lactating dairy cows exposed to heat stress often have rectal temperatures that reach or exceed $40 \mathrm{C}[23,24]$. There is the potential, therefore, for sperm in the reproductive tract to be damaged by exposure to elevated temperature. Most of the data presented here are not supportive of such a hypothesis. As compared to aging at $38.5 \mathrm{C}$, there was no effect of $40 \mathrm{C}$ on the fertilizing capacity of sperm as measured by pronuclear formation or on cleavage rate of oocytes at Day 3 after insemination. As compared to sperm at $38.5 \mathrm{C}$, aging at $40 \mathrm{C}$ did not reduce the proportion of oocytes and cleaved embryos becoming blastocysts. Aging of sperm at $40 \mathrm{C}$ also reduced the rate of polyspermy. This effect might reflect a reduction in motility or ability of sperm to attach to and penetrate the zona pellucida of the oocyte.

Developmental competence in the present study was evaluated to the blastocyst stage. One cannot rule out effects of sperm aging on embryo competence for development to later stages of embryogenesis. Studies in the rabbit using sperm exposed to heat shock in vitro [27] or in vivo [28] indicate increased embryonic loss at Day 9 or 12 after insemination.

One effect of aging sperm was on blastocyst sex ratio. In the absence of sperm aging, the sex ratio of blastocysts was skewed to males and aging at $38.5 \mathrm{C}$ resulted in a sex ratio close to an equal number of males and female embryos. A similar effect of sperm aging on the sex ratio of the resultant blastocysts has been seen elsewhere [33, 35, 36].

A preponderance of male blastocysts is a characteristic of the in vitro embryo production system in our laboratory [37-39] and other laboratories [33-36, 40, 41]. The reason for this bias in sex gender is not clearly understood. It has been reported that male embryos develop faster in KSOM than female embryos [42], making it more likely that the first emerging blastocysts would be male. However, the increased proportion of males for embryos produced with control sperm in the present study was seen for embryos becoming blastocysts by Day 7 and between Day 7 and 8 . Kimura et al. [43] demonstrated that glucose in excess of $1 \mathrm{mM}$ is toxic to female bovine embryos but the concentrations of glucose in embryo culture medium in the present experiment $(0.2 \mathrm{mM})$ was too low to be toxic [30]. It seems mostly likely that the gender bias is due to differential fertilizing ability of Y-bearing vs. X-bearing spermatozoa. In support of this are the findings that the sex bias occurs as early as the 4-8 cell stage [35] and that lengthening fertilization time beyond 5-6 h eliminated the male bias in the sex ratio of embryos [35, 36]. Iwata et al. [36] speculates that the more rapid fertilization achieved with Y-bearing sperm reflects earlier capacitation for Y-bearing sperm. Thus, it is likely that the reduction in the proportion of blastocysts that were male caused by aging of sperm at 38.5 $\mathrm{C}$ reflects differential effects of aging on fertilizing ability of Y-bearing and X-bearing sperm. Energy store depletion, free radical damage, membrane changes or other aging-associated changes [44-46] could occur more rapidly for Y-bearing sperm, particularly if they are more active because of earlier capacitation.

The reduction in male bias in sex ratio caused by aging at $38.5 \mathrm{C}$ was not significant when sperm were aged at $40 \mathrm{C}$. Possibly, aging at $38.5 \mathrm{C}$ affects $\mathrm{Y}$-bearing sperm preferentially while aging at a higher temperature results in aging-associated changes in both $\mathrm{Y}$ and X-bearing sperm.

The observation that aging of sperm can lead to changes in sex ratio of the resultant embryo points out the potential for changes in sperm function to effect the embryo formed by fertilization with that sperm. Nonetheless, despite nuclear and non-nuclear contributions of the sperm to the embryo [9], there was no evidence that the competence of the embryo to develop to the blastocyst stage was determined by aging at temperatures characteristic of normothermia or hyperthermia. Thus, at least under the conditions tested, damage to the sperm is more likely to lead to a reduction in fertilizing ability than to the cellular characteristics of the resultant embryo that determine its developmental potential.

\section{Acknowledgements}

Funding was provided by National Research Initiative Competitive Grants Program Grant No. 2007-35203-18070 from the U.S. Department of Agriculture Cooperative State Research, Education and Extension Service and by Research Grant No. US-3986-07 from BARD, the Binational Agricultural Research and Development Fund. The authors thank Marshall, Adam and Alex Chernin and the employees of Central Beef Packing Co. (Center Hill, FL, USA) for donation of ovaries and William Rembert for his assistance in collecting ovaries. 


\section{References}

1. Warner CM, McElhinny AS, Wu L, Cieluch C, Ke X, Cao W, Tang C, Exley GE. Role of the Ped gene and apoptosis genes in control of preimplantation development. $J$ Assist Reprod Genet 1998; 15: 331-337.

2. Sirard MA, Richard F, Blondin P, Robere C. Contribution of the oocyte to embryo quality. Theriogenology 2006; 65: 126-136.

3. Ménézo YJ. Paternal and maternal factors in preimplantation embryogenesis: interaction with the biochemical environment. Reprod Biomed Online 2006; 12: 616-621.

4. Baumann CG, Morris DG, Sreenan JM, Leese HJ. The quiet embryo hypothesis: molecular characteristics favoring viability. Mol Reprod Dev 2007; 74: 1345-1353.

5. Khatib H, Monson RL, Schutzkus V, Kohl DM, Rosa GJ, Rutledge JJ. Mutations in the STAT5A gene are associated with embryonic survival and milk composition in cattle. J Dairy Sci 2008; 91: 784-793.

6. Khatib H, Maltecca C, Monson RL, Schutzkus V, Wang X, Rutledge JJ. The fibroblast growth factor 2 gene is associated with embryonic mortality in cattle. J Anim Sci 2008; 86: 2063-2067.

7. Eid LN, Lorton SP, Parrish JJ. Paternal influence on S-phase in the first cell cycle of the bovine embryo. Biol Reprod 1994; 51: 1232-1237.

8. Kuroda K, Fukushima M, Harayama H. Premature capacitation of frozen-thawed spermatozoa from subfertile Japanese black cattle. J Reprod Dev 2007; 53: 1079-1086.

9. Sutovsky P, Schatten G. Paternal contributions to the mammalian zygote: fertilization after sperm-egg fusion. Int Rev Cytol 2000; 195: 1-65.

10. Ostermeier GC, Miller D, Huntriss JD, Diamond MP, Krawetz SA. Reproductive biology: delivering spermatozoan RNA to the oocyte. Nature 2004; 429: 154

11. Virro MR, Larson-Cook KL, Evenson DP. Sperm chromatin structure assay (SCSA) parameters are related to fertilization, blastocyst development, and ongoing pregnancy in in vitro fertilization and intracytoplasmic sperm injection cycles. Fertil Steril 2004; 81: 1289-1295.

12. Seli E, Gardner DK, Schoolcraft WB, Moffatt O, Sakkas D. Extent of nuclear DNA damage in ejaculated spermatozoa impacts on blastocyst development after in vitro fertilization. Fertil Steril 2004; 82: 378-383.

13. Muriel L, Garrido N, Fernández JL, Remohí J, Pellicer A, de los Santos MJ, Meseguer $\mathbf{M}$. Value of the sperm deoxyribonucleic acid fragmentation level, as measured by the sperm chromatin dispersion test, in the outcome of in vitro fertilization and intracytoplasmic sperm injection. Fertil Steril 2006; 85: 371-383.

14. Walters AH, Saacke RG, Pearson RE, Gwazdauskas FC. Assessment of pronuclear formation following in vitro fertilization with bovine spermatozoa obtained after thermal insulation of the testis. Theriogenology 2006; 65: 1016-1028.

15. Walters AH, Eyestone WE, Saacke RG, Pearson RE, Gwazdauskas FC. Sperm morphology and preparation method affect bovine embryonic development. J Androl 2004; 25: 554-563.

16. Walters AH, Eyestone WE, Saacke RG, Pearson RE, Gwazdauskas FC. Bovine embryo development after IVF with spermatozoa having abnormal morphology. Theriogenology 2005a; 63: 1925-1937.

17. Walters AH, Saacke RG, Pearson RE, Gwazdauskas FC. The incidence of apoptosis after IVF with morphologically abnormal bovine spermatozoa. Theriogenology 2005b; 64: 1404-1421.

18. Kim ST, Moley K. Paternal effect on embryo quality in diabetic mice is related to poor sperm quality and associated with decreased GLUT expression. Reproduction 2008 Online Jun 16.

19. Ahmadi A, Ng SC. Fertilizing ability of DNA-damaged spermatozoa. J Exp Zool 1999; 284: 696-704.

20. Brocas C, Rivera RM, Paula-Lopes FF, McDowell LR, Calhoun MC, Staples CR, Wilkinson NS, Boning AJ, Chenoweth PJ, Hansen PJ. Deleterious actions of gossypol on bovine spermatozoa, oocytes, and embryos. Biol Reprod 1997; 57: 901-907.

21. Silva PF, Gadella BM, Colenbrander B, Roelen BA. Exposure of bovine sperm to prooxidants impairs the developmental competence of the embryo after the first cleavage. Theriogenology 2007; 67: 609-619.

22. Monterroso VH, Drury KC, Ealy AD, Edwards JL, Hansen PJ. Effect of heat shock on function of frozen/thawed bull spermatozoa. Theriogenology 1995; 44: 947-961.

23. Elvinger F, Natzke RP, Hansen PJ. Interactions of heat stress and bovine somatotropin affecting physiology and immunology of lactating cows. J Dairy Sci 1992; 75: 449462.

24. de Castro E Paula LA, Andrzejewski J, Julian D, Spicer LJ, Hansen PJ. Oxygen and steroid concentrations in preovulatory follicles of lactating dairy cows exposed to acute heat stress. Theriogenology 2008; 69: 805-813

25. Hansen PJ. Exploitation of genetic and physiological determinants of embryonic resistance to elevated temperature to improve embryonic survival in dairy cattle during heat stress. Theriogenology 2007; 68 (Suppl 1): 242-249.

26. Mann SL, Patton WC, King A, Chan PJ. Comparative genomic hybridization analysis of sperm DNA apoptosis after exposure to heat shock. J Assist Reprod Genet 2002; 19 : 195-200.

27. Burfening PJ, Ulberg LC. Embryonic survival subsequent to culture of rabbit spermatozoa at 38 and 40 C. J Reprod Fertil 1968; 15: 87-92.

28. Howarth B Jr, Alliston CW, Ulberg LC. Importance of uterine environment on rabbit sperm prior to fertilization. J Anim Sci 1965; 24: 1027-1032.

29. Parrish JJ, Susko-Parrish JL, Critser ES, Eyestone WH, First NL. Bovine in vitro fertilization with frozen-thawed semen. Theriogenology 1986; 25: 591-600.

30. Soto P, Natzke RP, Hansen PJ. Identification of possible mediators of embryonic mortality caused by mastitis: actions of lipopolysaccharide, prostaglandin $F_{2 \alpha}$, and the nitric oxide generator, sodium nitroprusside dihydrate, on oocyte maturation and embryonic development in cattle. Am J Reprod Immunol 2003; 50: 263-272.

31. Park JH, Lee JH, Choi KM, Joung SY, Kim JY, Chung GM, Jin DI, Im KS. Rapid sexing of preimplantation bovine embryo using consecutive and multiplex polymerase chain reaction (PCR) with biopsied single blastomere. Theriogenology 2001; 55: 18431853.

32. Pollard JW, Plante C, King WA, Hansen PJ, Betteridge KJ, Suarez SS. Fertilizing capacity of bovine sperm may be maintained by binding of oviductal epithelial cells. Biol Reprod 1991; 44: 102-107.

33. Lechniak D, Strabel T, Bousquet D, King AW. Sperm pre-incubation prior to insemination affects the sex ratio of bovine embryos produced in vitro. Reprod Domest Anim 2003; 38: 224-227.

34. Agung B, Otoi T, Wongsrikeao P, Taniguchi M, Shimizu R, Watari H, Nagai T Effect of maturation culture period of oocytes on the sex ratio of in vitro fertilized bovine embryos. J Reprod Dev 2006; 52: 123-127.

35. Kochhar HS, Kochhar KP, Basrur PK, King WA. Influence of the duration of gamete interaction on cleavage, growth rate and sex distribution of in vitro produced bovine embryos. Anim Reprod Sci 2003; 77: 33-49.

36. Iwata H, Shiono H, Kon Y, Matsubara K, Kimura K, Kuwayama T, Monji Y. Effects of modification of in vitro fertilization techniques on the sex ratio of the resultant bovine embryos. Anim Reprod Sci 2008; 105: 234-244.

37. Block J, Drost M, Monson RL, Rutledge JJ, Rivera RM, Paula-Lopes FF, Ocon OM Krininger CE $3^{\text {rd }}$, Liu J, Hansen PJ. Use of insulin-like growth factor-I during embryo culture and treatment of recipients with gonadotropin-releasing hormone to increase pregnancy rates following the transfer of in vitro-produced embryos to heat-stressed, lactating cows. J Anim Sci 2003; 81: 1590-1602.

38. Block J, Hansen PJ. Interaction between season and culture with insulin-like growth factor-1 on survival of in vitro produced embryos following transfer to lactating dairy cows. Theriogenology 2007; 67: 1518-1529.

39. Franco M, Block J, Jousan FD, de Castro e Paula LA, Brad AM, Franco JM, Grisel F, Monson RL, Rutledge JJ, Hansen PJ. Effect of transfer of one or two in vitro-produced embryos and post-transfer administration of gonadotropin releasing hormone on pregnancy rates of heat-stressed dairy cattle. Theriogenology 2006; 66: 224-233.

40. King WA, Yadar BR, Xu K P, Picard L, Sirard MA, Supplizi AV, Betteridge KJ. The sex ratio of bovine embryos produced in vitro and in vivo. Theriogenology 1991; 36: 779788

41. Hasler JF, Cardey E, Stokes JE, Bredbacka P. Nonelectrophoretic PCR-sexing of bovine embryos in a commercial environment. Theriogenology 2002; 58: 1457-1469.

42. Nedambale TL, Dinnyes A, Yang X, Tian XC. Bovine blastocyst development in vitro: timing, sex, and viability following vitrification. Biol Reprod 2004; 71: 1671-1676.

43. Kimura K, Spate LD, Green MP, Roberts RM. Effects of D-glucose concentration, Dfructose, and inhibitors of enzymes of the pentose phosphate pathway on the development and sex ratio of bovine blastocysts. Mol Reprod Dev 2005; 72: 201-207.

44. Vishwanath R, Shannon P. Do sperm cells age? A review of the physiological changes in sperm during storage at ambient temperature. Reprod Fertil Dev 1997; 9: 321-331

45. Krzyzosiak J, McMillan G, Molan P, Vishwanath R. Protein tyrosine phosphorylation during prolonged in vitro incubation of ejaculated bovine spermatozoa is regulated by the oxidative state of the medium. Biol Reprod 2000; 62: 1615-1623.

46. Krzyzosiak J, Molan P, McGowan L, Vishwanath R. Effect of sperm number and oxygenation state of the storage media on in vitro fertility of bovine sperm stored at ambient temperature. Theriogenology 2001; 55: 1401-1415. 